\title{
Post-merger Integration - Management of Intercultural Differences between a Japanese Corporation and a German Hidden Champion
}

\author{
Intelmann Michael, Wellner Kai-Uwe* \\ International Business at the Nuremberg Institute of Technology University, Georg-Simon-Ohm, Germany
}

Copyright $(2017$ by authors, all rights reserved. Authors agree that this article remains permanently open access under the terms of the Creative Commons Attribution License 4.0 International License

\begin{abstract}
The purpose of this paper is to indicate obvious aspects with regard to differences in national and organisational cultures in co-operations between two international companies and to give suggestions how to resolve them. Based on a series of qualitative and quantitative interviews, the following research presents an acquisition from a Bavarian, countryside medium-sized German automation company (PLC company with roughly EUR 30 million Sales and 250 employees) by an international Japanese machinery building corporation (acting in same field of business with a stronger focus on the machinery building, stock listed co-operation with roughly EUR 3 billion sales and 14.000 employees). The article outlines cultural and management integration strategies to ensure successful collaboration for the future to secure the strength of the German medium-sized company. The findings show that the personal readiness to understand, adapt and tolerate the cultural differences helps to facilitate negotiations and though, the process of cultural integration is a soft topic and takes several years, it can and should be planned systematically and precisely integrated by the top management to achieve effective change for the realisation of synergies. The elaborated suggestions are helpful for managers in general, because the often underestimated topic of cultural integration, is at least as important for the valuable outcome of the co-operation as strategic and organisational changes.
\end{abstract}

Keywords Managing Intercultural Differences, Cultural Integration, Post-merger Integration, Mid/Medium Size Company, Hidden Champions, German/Japanese Collaboration

\section{Importance of Culture in the Surveyed Merger}

In an increasingly globalised world, international business co-operations with strategic investments, such as joint ventures, strategic alliances, foreign subsidiaries as well as mergers and acquisitions (M\&A), become more and more frequent. Such collaborations inhibit several challenges. Particularly, M\&A involve major adaptations at one or both organisations in terms of strategy, business processes, communication and corporate culture [1].

Managers often analyse internal organisational structures and environmental forces, but neglect socio-cultural and political processes which also strongly influence decisions at all operational levels [2]. George Bradt [3] even goes as far to say that every other factor of consolidation is merely a derivative of the cultural, or better said attitudes of doing business, integration.

According to an Aon Hewitt study, M\&A fail in 60-70\% [4] of the cases to create value for the merging companies and $33 \%$ of managers blame the diverse attitude of doing business integration for this failure while $50 \%$ of them admit it was the main post-deal challenge [5]. Since in international co-operations, two kinds of culture - national and organisational - encounter each other, it is helpful to shed some light on how the consolidation can be facilitated [6].

The following sections present challenges caused by the differences in national and organisational cultures in the course of the consolidation process between a German (X) and a Japanese (Y) company, and gives suggestions on how to overcome them. The findings are chiefly based on the scientific literature review of leading contributors and specialists in this area. Furthermore, the author has conducted a series of qualitative interviews with nearly $30 \%$ of the employees and middle management of the German company as well as with $100 \%$ of the top management from both organisations $\left(=1^{\text {st }}\right.$ senior management level of both companies, the German medium-sized company and the already existing German subsidiary of the Japanese company) in Germany. These interviews served as a basis for the subsequent quantitative survey concerning the integration process among employees at X. Last but not least, the author has worked closely together with the German company 
allowing to undertake corresponding observations and provide deep insight over 9 month in 2015 and 2016 from inside the German company $\mathrm{X}$. The internal information helped to support the statements found in the literature review and demonstrate them by help of the case study.

\section{Background of the Companies}

\subsection{German Medium-sized Company X}

$\mathrm{X}$ is a medium-sized company - headquartered in Bavaria, Germany - with roughly 250 employees and EUR 30 million annual turnover. Production is mainly generated in Germany but also with supplying parts in Asia. Its primary market with $50 \%$ of their sales is Germany, but it is also active in several international countries with a strong focus on Europe. It caters chiefly to small and medium-sized enterprises (SME).

$\mathrm{X}$ has typical advantages of a medium-sized German engineering company and has convinced its customers with high service availability, fast reaction times and customer-oriented flexibility. The company has sought to position itself as lateral thinking. It has also scored with a lower price leadership over the last decades by using Asian sourced semi parts. Main production and research are based in the German headquarter. Flexibility, innovation, closeness to customers and high quality are key strength of the product creation process. Closeness to customers and relationship management in the niche are their assets. The company $\mathrm{X}$ specialises their automation business in a product niche. They can be seen in their niche as Hidden Champion (see chapter 3.1) [7].

The internal organisational culture of $\mathrm{X}$ has been coined by family-like atmosphere with many common sports events and leisure activities, easy-going working culture, low bureaucracy and flexible working processes but high pressure to achieve excellence in R\&D, Sales, Service and production. The scrutiny and reporting functions have run at a low rate and the hierarchy structures have been flat to support fast decision taking [4]. The strong employee-orientated management approach ranks employee satisfaction very high and creates a high feeling of belonging between the personnel. The communication style can be described as open focused and direct.

$\mathrm{X}$ has been led by a charismatic founder, who has been identifying company's course without a particular long-term strategy but a strong personal leadership skill and engagement. Similarly, the focus of R\&D activities was chiefly focused on the next few years. With 2 major (non SME) competitors in the same market, the company has developed an underestimated, underdog attitude.

\subsection{Japanese Multinational Corporation Y}

$\mathrm{Y}$ is a multinational corporation with roughly 14,000 employees worldwide and EUR 3 billion annual turnover, headquartered in Japan and active in the same industry as X. With a long legacy of over a century, Y can be described as traditional and long-term oriented. The products demonstrate high quality, safety and reliability and hence, are normally priced over the industry average. The corporation exhibits a market-leading position in Asia and North America and is an established supplier for large and international customers.

$\mathrm{Y}$ is positioned as a technology-driven company with lengthy R\&D processes of over 5 years and long-term strategic planning. Typically for a Japanese company, $\mathrm{Y}$ has strict hierarchy levels and follows bureaucratic working processes, supporting the stability of the business. The scrutiny and reporting degrees are substantially higher and much more detailed than at $\mathrm{X}$.

$\mathrm{X}$ 's acquisition can be considered as a vertical backward integration along the supply chain from Y's perspective. Besides, the term "merger" instead of "acquisition" was chosen for the consolidation process, as $\mathrm{Y}$ has committed to preserve the former culture and processes at its new German acquisition. $\mathrm{Y}$ has for several years major subsidiary in Germany focusing on Sales, Marketing, Warehouse, R\&D and Production with about 1200 employees in 3 locations.

Though, technically, Y's European subsidiary has acquired $\mathrm{X}, \mathrm{Y}$ is still highly involved in the post-merger integration process from Japan. For example, the top management meetings have a substantial political influence on future X's business development. This is the reason, that German-Japanese cultural barriers and ways of doing business still exist and these will be addressed in the following paragraphs.

\section{The Market for Japanese-German Mergers and Acquisitions}

When discussing the management of M\&As with German companies, particularly with small and medium-sized enterprises, it is crucial to take into account not only the cultural differences amongst the merging partners, but also to consider the unique company structure of each side of the deal. The following section describes the unique position and market impact of Hidden Champions, a noteworthy group of enterprises in Germany, which would like play the role of X in a large part of international collaborations with Japanese companies.

\subsection{The importance of German SMEs and Hidden Champions}

The German company X described in section 2.1 can be considered a generic example of a small but highly impactful branch of companies in the German market. The market is primarily comprised of three sizes of firms: small companies (98.9\% of the enterprises in Germany), Mittelstand or medium-sized companies (roughly 1\%) and large corporations $(0.1 \%)$. While comparatively small in number, 
the medium-sized enterprises generate $37.9 \%$ of the total revenue of all of the firms in Germany, surpassing both large corporations and small companies in overall performance. These businesses furthermore employ one third of the German business sector workforce [8].

As a term of a Hidden Champion (HC) has been mentioned with regard to company $\mathrm{X}$, it is beneficial to identify characteristics of a $\mathrm{HC}$ and its strengths and risks in the light of the upcoming analysis.

HCs are a unique type of medium-sized companies that, while being relatively unknown to the general public, tend to become the market leader or a top 3 supplier in their respective niche or market [9]. A study by Rammer \& Spielkamp [10] revealed that there are approximately 1,500 such companies operating in the German market at the time, on average holding a 34\% market share in their individual niches, generating $11.3 \%$ revenue growth yearly and owning $64 \%$ of their revenues to exports and trade abroad. Figure 1 shows incremental growth of HCs in Germany over the last 2 decades.

Pursuant to Hermann Simon [12] and [13] and Wellner [11], a HC normally fulfills the following criteria:

1) Medium-sized in terms of employees and/or revenue and hence, flat hierarchies $\mathrm{X}$, with roughly 250 employees and EUR 30 million annual turnover, can be considered medium-sized.

2) Top 3 worldwide or No. 1 on its continent $X$ has a worldwide presence in its niche of the automation industry.

3) Situated in rural areas or next to major regional centers X's headquarters are located on the outskirts of a metropolis-region.

4) Sustainable business in the long run $X$ has been in business for a few decades.

5) Its competitive advantage (e. g. innovation, service/product quality, etc.) is added at the headquarters (e. g. in Germany). X's main production and $\mathrm{R} \& \mathrm{D}$ are located at its headquarters in Germany.

6) Strong internationalisation strategy and high revenue share abroad (close to $50 \%$ ) (Common HCs strength: proximity to customer - worldwide). Around half of the sales at X are done abroad.

7) Strong ownership spirit by the management, often family-owned businesses and no principle-agent problem $\mathrm{X}$ was led long time by its founder.

8) Small level of public awareness and thus, often operating in Business-to-Business (B2B) operations $\mathrm{X}$ is exclusively operating in $\mathrm{B} 2 \mathrm{~B}$ and therefore, is not known by the general public.

The unique branch of companies could be particularly interesting in the context of a Japanese-German cooperation, as Hidden Champions not only cooperate extensively abroad, but also repeatedly exhibit strategic interest in founding subsidiaries outside of Europe (22.1\%), outsourcing business processes $(11.7 \%)$, selling parts of their firm $(11.0 \%)$ and the acquisition of other companies (19.3\%), all of which offer room for cooperation with Japanese firms. Alongside classic M\&A activities, Hidden Champions are generally particularly interested in outsourcing business processes that can be carried out more efficiently by third parties [10]. Outsourcing such activities allows the companies to specialize further, shifting their focus away as much as possible from tasks which are not related to their core business. The firms oftentimes focus solely on increasing their know-how and improving their manufacturing processes, choosing to form alliances or cooperate in other forms with other (foreign) firms for all other activities.

Hidden Champions generally surpass all other types of companies in their interest in expanding or cooperating outside of Europe [10]. A recent case study by Wellner [7] analysed three worldwide markets leading $\mathrm{HCs}$ in the Bavarian region of Coburg in Germany (LASCO Umformtechnik $\mathrm{GmbH}$, Waldrich Coburg $\mathrm{GmbH}$ and Kaeser $\mathrm{GmbH}$ ) revealed that internationalization is seen as an important success factor for companies of this nature. Contrary to the tendency of international companies to outsource production to low-wage countries in order to cut costs, the main reason why Hidden Champions choose to expand to foreign markets is to be able to build closer, more reliable relationships with their customers and partners. The companies view customer proximity, service quality and reliability and internationalization as their key success factors, generating above-average margins as a result (see Figure 7). The companies also revealed that having an international presence with local production plants, logistics centres and sales offices enhances the resilience of the firms' core business to market shifts, granting further stability to the activities the companies have specialized in [7].

However, there are also risks of being a $\mathrm{HC}$ : not only "constant, aggressive pricing and innovation-driven competition burdens the margins of the companies" [14] but also companies exhibit difficulties to find professionals, especially if they are located in a more rural area [14]. It is connected with the lack of branding and marketing [11]. Along with these challenges, it became apparent in the case of $\mathrm{X}$, that limited financial resources and dependency on a narrow product line make it, but also any other medium-sized company, prone to liquidity problems and crises. This is true despite their geographical distribution given the fact, that their central competencies are situated at headquarters. One of the advantages of the merger was exactly to overcome these two risks by integrating own products into the portfolio of a bigger company and secure financial liquidity in difficult times.

It is therefore clear that German HCs would most likely play the role of company $\mathrm{X}$ in a large number of international cooperations with Japanese Y firms. The focus of Hidden Champions on long-term mutually beneficial customer relationships and on high quality innovative products and services brings together both the German and Japanese cultural aspects described above. Even though partnerships 
between a Hidden Champion X and Y would most likely face the same initial broad cultural challenges as other firms, there is nonetheless a high chance that the companies will be able to merge and cooperate much more smoothly on an operational and strategic level, as the two companies' understanding of what matters in a firm will on average be closely aligned, more so than when $\mathrm{X}$ is a different type of company [7].

\subsection{Japanese Investments and Collaborations with German HCs}

As noted by Simon and Lippert [15], Hidden Champions tend to be particularly interested in conducting business in Japan or with Japanese firms, most notably due to the extreme lengths to which Japanese firms tend to emphasize quality and technological improvement. These two attributes tend to be not only the most valued virtues of German Hidden Champions, but also to a large extent what they consider to be their key success factors. Surveys have shown that $82 \%$ of German HCs offering their products and services to Japanese customers felt Japanese quality standards and demands were at least $10 \%$ and to a large extent more than $30 \%$ higher than the German ones [15].

Nonetheless, Hidden Champions have faced several difficulties in expanding into the Japanese market, most notably in entering the market, dealing with customers, finding and maintaining partners, creating subsidiaries or forging co-operations with companies that match the processes and standards of the $\mathrm{HC}$, as well as finding suitable Japanese personnel. A large part of these issues can be reduced to the fundamental differences in mentality, corporate culture and the way of doing things in business, as discussed earlier in this article. The comparatively instable and fragmented Japanese economy has also further inhibited the growth of the HCs operations in the market [16].

While such investments by German HCs have proven to be wildcards that can either lead to successful operations in the market or backfire altogether, there are little to no examples of Japanese Hidden Champions or other SMEs investing in or acquiring German firms, even though they exhibit similar characteristics and ideals [7]. This can be partially attributed to the fact that such companies tend to focus almost exclusively on the Japanese market. The market structure also further inhibits the growth of Japanese HCs abroad, due to its hierarchical structure in which large corporate conglomerates steer the direction of the economy, while smaller and medium-sized companies are forced to follow their lead [15]. Not only do German HCs struggle to find suitable personnel in Japan, but Japanese HCs themselves also have difficulties in recruiting highly talented international-minded employees, as these generally see HCs as comparatively unattractive employers, targeting Japanese conglomerates and international large corporations instead [16].

Japanese companies, most notably HCs, could however benefit greatly from cooperating or forging alliances with
German partners. Germany is still Japan's biggest largest investment target within the European Union, becoming home to 235 Greenfield projects (a quarter of all EU projects) between 2008 and 2013 [17]. The most important sectors for investment in Germany included the automotive industry, the mechanical engineering industry and the electronics and semiconductor industries (supporting 52\% of all Japanese FDI projects in Germany). The most important reported reasons for FDI investments included setting up sales offices (39\%), setting up production facilities (17\%) and setting up headquarters (12\%) in Germany [17].

While mergers and cooperation amongst German and Japanese small and medium-sized companies, most notably HCs, might be limited in number at the moment, recent announcements suggest that this could increasingly change in the future, with increasingly more Japanese companies investing in or purchasing smaller firms in Germany. The most recent example of such a purchase is the family-run Japanese company Musashi that has announced its plans to acquire the German automotive supplier Hay [18], Cooperations between the businesses of the two countries, both in terms of joint ventures (e.g. BASF and Toda-Kogyo's battery projects) and simple knowledge sharing (e.g. the JETRO symposium on Japanese and German SMEs and Hidden Champions that took place in Frankfurt/Main in 2015) will likely see further growth in the future.

\section{Cultural Comparison}

\subsection{Hofstede Dimensions between Germany and Japan}

According to Hofstede, a culture "is the collective programming of the mind that distinguishes the members of one group or category of people from others" [19]. This chapter is focusing on describing the characteristics of the German and Japanese national cultures in order to provide theoretical background for the upcoming post-merger integration framework.

Figure 3 compares German and Japanese country cultures based on dimensions of Geert Hofstede. The chart helps to identify key drivers for the people's behaviour belonging to the one or the other culture.

The Power Distance describes how people with less power "expect and accept that power is distributed unequally" [20]. Thus, it shows how much hierarchy structure they wish to have in their society. Though Japanese companies normally consist of multiple hierarchical levels, which slow down decision taking, it actually shows that a decision cannot be solely taken by one person, but has to be confirmed by several members of the organisation. Therefore, in spite of being aware of the own personal position, the Japanese have comparably less hierarchy than other Asian countries. Germany exhibits a smaller value on this dimension. In business, co-determination of associates of all levels and participative 
communication and management style indicate the tendency to flat hierarchies and little control. Leaders are mostly accepted through individual expertise not a hierarchical position [20]. Hidden Champions (such as X), being medium-sized companies, have relatively small number of employees and thus, little need for strict hierarchies, in contrast to big company $\mathrm{Y}$. Thus, the contrast of power distance becomes stronger for these types of companies and creates room for potential conflicts.

The Individualism dimension defines "the degree of interdependence a society maintains among its members". High value would indicate high degree of individuality, whilst low value shows high degree of collectivism. Though, the Japanese tend to show collective behaviour, as they prefer to love group harmony and "have a strong sense of shame for losing face" [20], they are not that collectivistic as other Asian countries, exemplified among others by living in smaller families (similar to Germans). Germany is more individualistic than Japan, shown by direct communication style and a drive for self-actualisation. The two countries are similar, as they both live in smaller families and prefer to decide themselves to which company they want to be loyal to [20]. In the light of the two companies $\mathrm{X}$ and $\mathrm{Y}$, this enables managers to reward employees based on their performance and achieve personnel motivation in a similar way. However, one should keep in mind, that big traditional Japanese companies perceive long working hours and lengthy company association also as a reason to reward their employees.

Cultures with a high value on the Masculinity dimension strive for success and achievement, while feminine countries value more the quality of life and caring for others. Japanese live in order to work [20]. The work is seen as a virtue, since it earns own acceptance in society and allows taking care of oneself and own family [21]. Germany - though less than Japan - is still considered as a marginally masculine society, as people tend to identify with their profession and draw much of self-esteem from their work [20]. Once again the similarities come to light and create common ground to base post-merger integration work between company $\mathrm{X}$ and $\mathrm{Y}$. Yet, one should still accept the differences on this scale. One example are the long holidays in Germany that can be taken all at once and perceived as absolutely uncommon by some Japanese managers.

As future cannot be known by anyone, the dimension of Uncertainty Avoidance exhibits the level of how much people want to control it. Japanese culture is highly uncertainty averse, reasoned by the facts that the population is permanently threatened by nature catastrophes and the ceremonies still play a major role in society. Strict etiquette rules exist to increase the predictability [20]. For example, $\mathrm{Y}$ has placed relatively high importance on elaboration of and adherence to forecast figures. Furthermore, displayed nameplates on tables define seating arrangements in a meeting and the ritual exchange of business cards serves to identify mutual hierarchy statuses (as in several other companies). These preparations decrease uncertainty and the risk of faux pas, leading to the potential loss of face [22]. Germans are also averse to ambiguity and unpredictability even if to a smaller degree than the Japanese. For instance, they are detail-oriented and put emphasis on the compliance with laws [20].

Cultures with a high value for Long Term Orientation focus rather on present and future achievements. Low value indicates holding on to the past, prioritising quick wins and resisting change. Japanese businesses put a lot of emphasis on long-term development in business, with examples such as, high R\&D investment, high own capital rate, steady growth instead of short-term profits [20]. Pursuant to an R\&D manager of $X$, these attributes are also accurate for $Y$, particularly in R\&D departments. And even though $\mathrm{X}$ was used to react quickly to market needs, the new perspective was welcomed at the German Hidden Champion, which can be explained by similar values for Germany and Japan in this dimension.

The last dimension is Indulgence vs Restraint and describes "the extent to which people try to control their desires and impulses" [20]. Low value indicates a restriction of own desires by social norms. High value indicates a relatively free gratification of personal needs related to enjoying life. Both, Japan and Germany are slightly restraint cultures with similar values, which speak for a tendency to cynicism and discipline, but less emphasis on leisure time. This is a similarity, which should cause little problems in collaboration.

To sum it up, the two national cultures are not that different as they might appear at the first glance. Sometimes, the Japanese are even called the Germans of Asia, because of the common tendency to punctuality, discipline and detail-orientation. At this point it should be mentioned, that not all Japanese or Germans have exactly the same drivers as described in this chapter. Every person is individual. However, the dimensions describe the overall inclination to certain values and behaviour, and provide a valid theoretical background that could be verified during the work with the two companies and that should be kept in mind during integration work.

\subsection{GLOBE Project Research Programme Comparing Germany and Japan}

The GLOBE Project stands for Global Leadership and Organizational Behaviour Effectiveness research programme that investigates differences between cultural societies across the world by help of over 170 researchers in 62 nations. The publication in 2004 is based on an 11-years study and focuses on cultural differences in values and practices. The GLOBE research team has narrowed down the comparison to totally 9 cultural dimensions, the definition of which is understood similarly across different 
nations. This allows an effective comparison, which should be presented in this chapter and discussed given the case study at hand [23].

The research that has started in early 1990s compares not only values (how it should be) of different national cultures (compare with chapter 4.1 on Hofstede dimensions) but also the actual practices (as it is in reality) in individual dimensions. These two figures for one dimension are rarely the same. In fact, often they seem to influence each other in opposite directions. The data may be interpreted, that people appreciate certain values more the less they actually follow them in real life (=practices) and vice versa [23].

The country data is provided by the GLOBE project and assigns individual scores from 1 (very low score in this dimension, e. g. not assertive at all) to 7 (very high score in this dimension, e. g. highly assertive) separately to each of the nine values and nine practices for each nation. For the following analysis the score between Germany and Japan should be compared and discussed in the light of the two companies $\mathrm{X}$ and $\mathrm{Y}$. As a side note, it should be mentioned that data was collected for East and West Germany separately. Yet, due to simplification reasons a mean value of the two country parts should be taken for comparison between the two nations [24]. Figure 4 depicts the statistical value of the upcoming analysis. Figure 5 shows a graphical representation from a minimum to maximum value (blue bars) and Japanese (red diamonds) and German score (orange diamonds) on each scale.

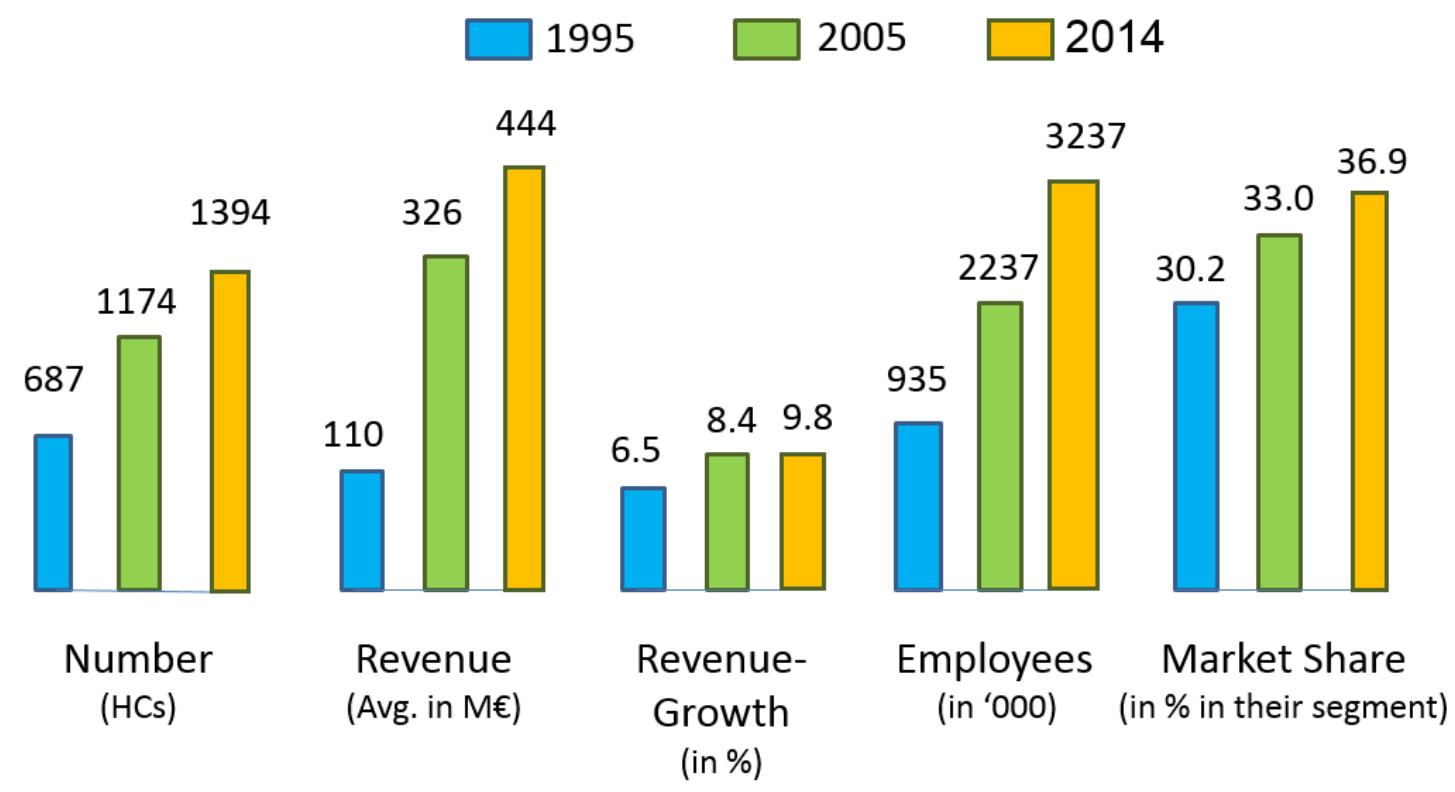

Figure 1. Position and Development of Hidden Champions in Germany [11] 


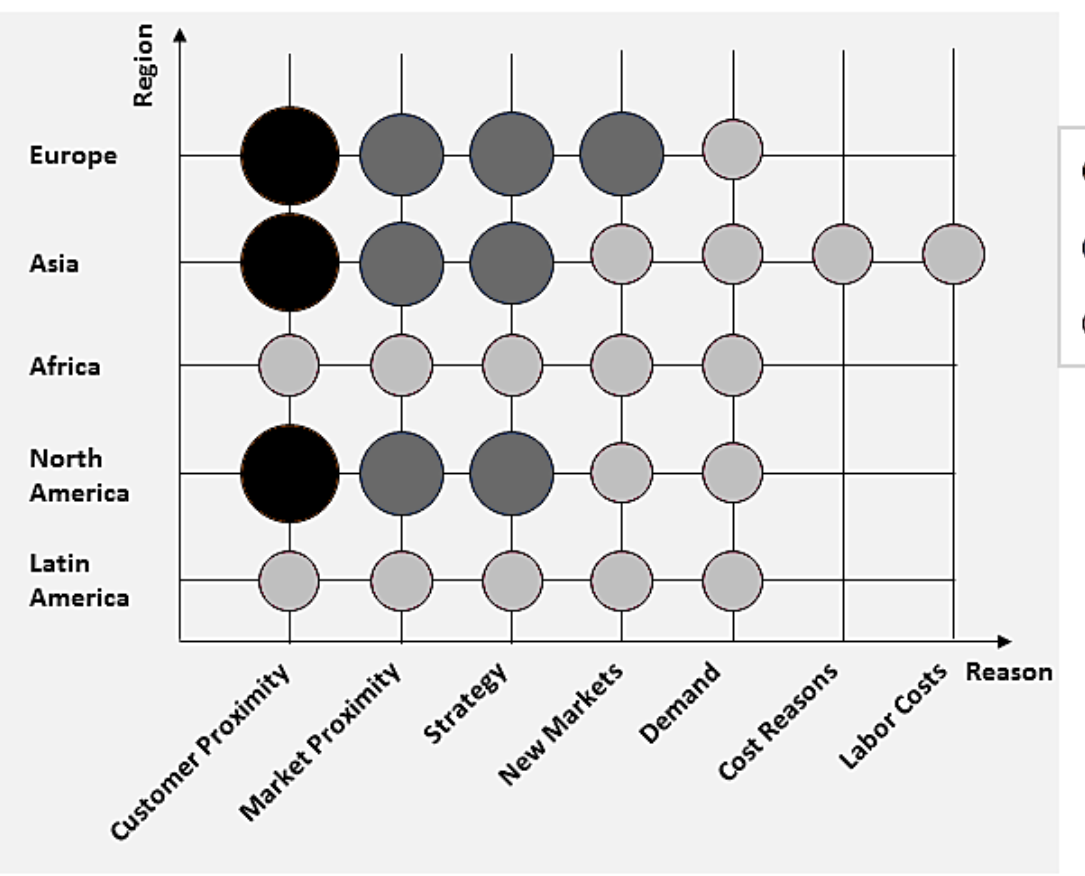

Relevant for three of the surveyed companies

Relevant for two of the surveyed companies

Relevant for one of the surveyed companies

Figure 2. Main reasons for the internationalization of Hidden Champions [7]

\section{Japan}

in comparison with Germany

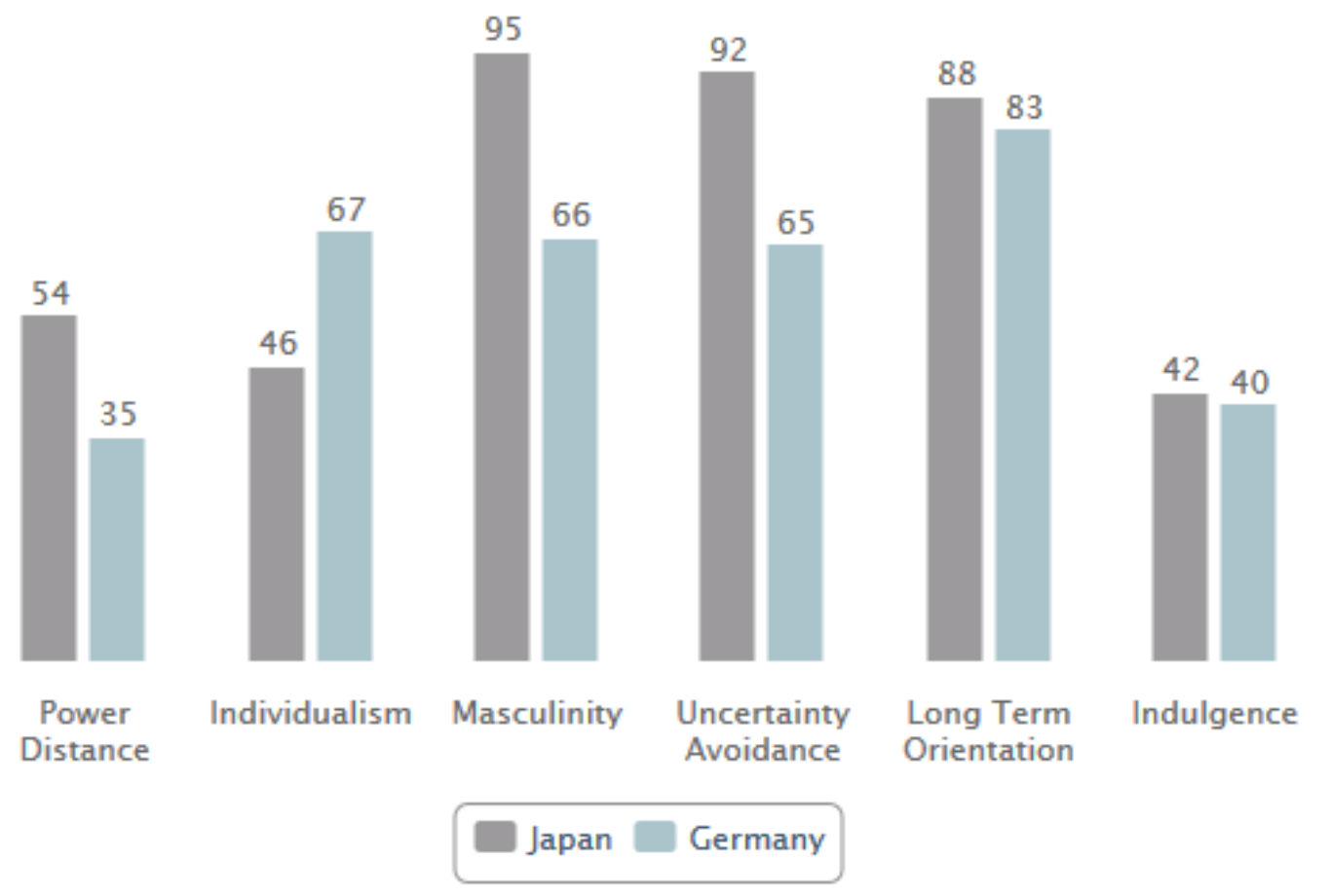

Figure 3. Comparison of national cultures of Japan and Germany [20] 


\begin{tabular}{|c|c|c|c|c|c|c|c|c|c|c|}
\hline & & $\begin{array}{l}\text { Uncertainty } \\
\text { Avoidance }\end{array}$ & $\begin{array}{c}\text { Future } \\
\text { Orientation }\end{array}$ & Power Distance & $\begin{array}{c}\text { Collectivism I } \\
\text { (Institutional } \\
\text { Collectivism) }\end{array}$ & $\begin{array}{c}\text { Humane } \\
\text { Orientation }\end{array}$ & $\begin{array}{c}\text { Performance } \\
\text { Orientation }\end{array}$ & $\begin{array}{l}\text { Collectivism II } \\
\text { (In-group } \\
\text { Collectivism) }\end{array}$ & $\begin{array}{c}\text { Gender } \\
\text { Egalitarianism }\end{array}$ & Assertiveness \\
\hline \multirow{6}{*}{ Practices } & Japan & 4,1 & 4,3 & 5,1 & 5,2 & 4,3 & 4,2 & 4,6 & 3,2 & 3,6 \\
\hline & Germany & 5,2 & 4,1 & 5,4 & 3,7 & 3,3 & 4,2 & 4,3 & 3,1 & 4,6 \\
\hline & Mean & 4,2 & 3,8 & 5,1 & 4,2 & 4,1 & 4,1 & 5,1 & 3,4 & 4,1 \\
\hline & Std. dev. & 0,6 & 0,5 & 0,5 & 0,4 & 0,5 & 0,4 & 0,8 & 0,4 & 0,4 \\
\hline & Min & 2,9 & 2,9 & 3,6 & 3,2 & 3,2 & 3,2 & 3,2 & 2,5 & 3,4 \\
\hline & Max & 5,4 & 5,1 & 5,8 & 5,2 & 5,2 & 4,9 & 6,4 & 4,1 & 4,9 \\
\hline \multirow{6}{*}{ Values } & Japan & 4,3 & 5,3 & 2,9 & 4,0 & 5,4 & 5,2 & 5,3 & 4,3 & 5,6 \\
\hline & Germany & 3,6 & 5,0 & 2,6 & 4,7 & 5,5 & 6,1 & 5,2 & 4,9 & 3,2 \\
\hline & Mean & 4,6 & 5,4 & 2,8 & 4,7 & 5,4 & 5,9 & 5,6 & 4,5 & 3,8 \\
\hline & Std. dev. & 0,6 & 0,5 & 0,4 & 0,5 & 0,4 & 0,6 & 0,4 & 0,5 & 0,6 \\
\hline & Min & 3,2 & 3,0 & 2,0 & 3,8 & 3,4 & 2,3 & 4,1 & 3,2 & 2,7 \\
\hline & Max & 5,6 & 6,2 & 4,4 & 5,7 & 6,1 & 6,6 & 6,5 & 5,2 & 5,6 \\
\hline
\end{tabular}

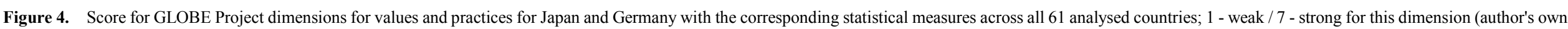
work based on [24]) 


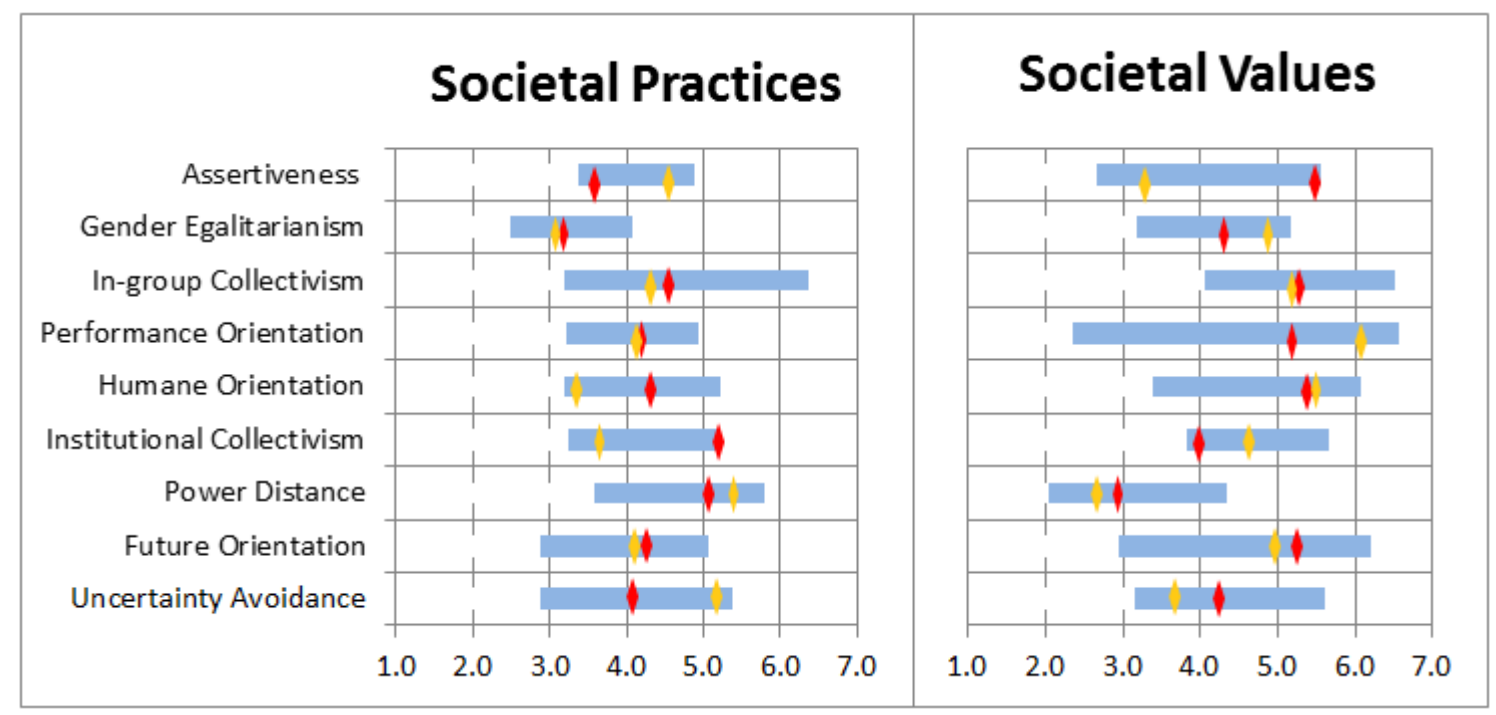

Figure 5. Societal practices and values depicted graphically show several similarities between German and Japanese cultures (red: Japan, orange: Germany) (author's own work based on [24])

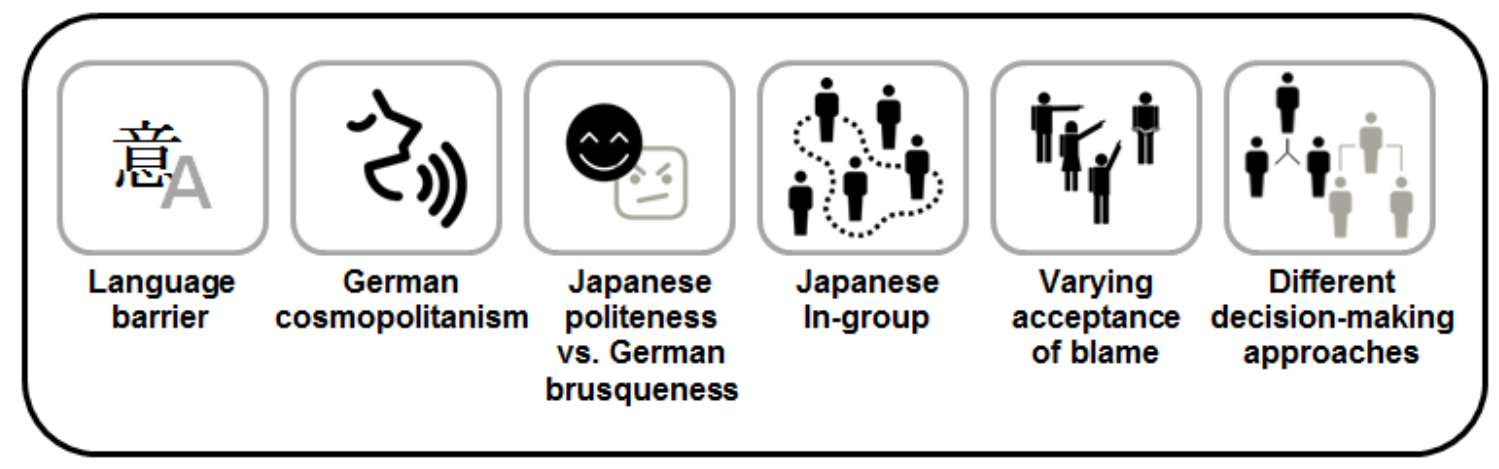

Figure 6. Overview of the presented differences between the German and Japanese national cultures (author's own work based on [25])

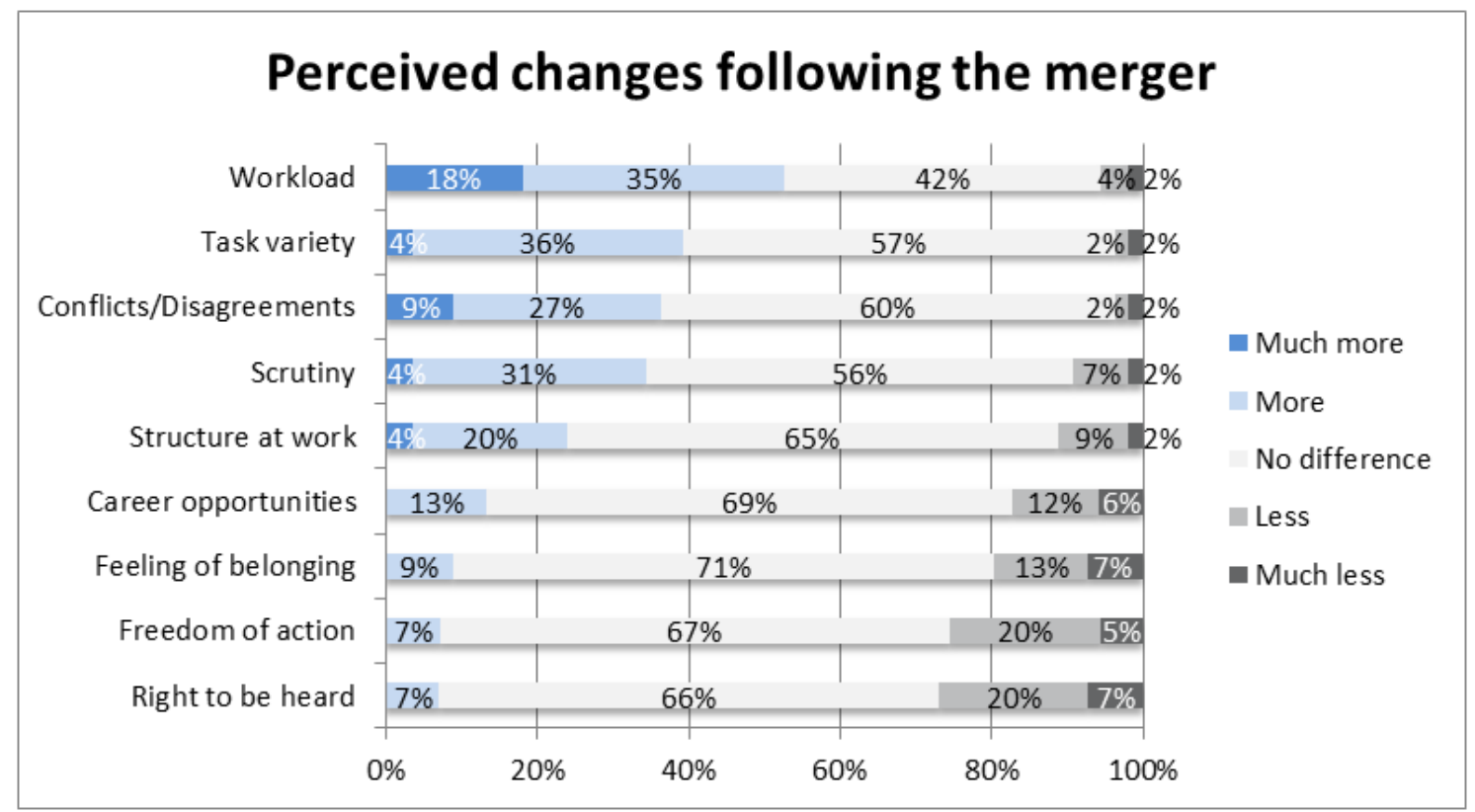

Figure 7. Perceived changes 3 years after the merger (author's own work) 
Too long decision taking processes at $Y$

Too rigid hierarchical structure at $Y$

Different culture / mindset at $Y$

Language barrier

Separate locations

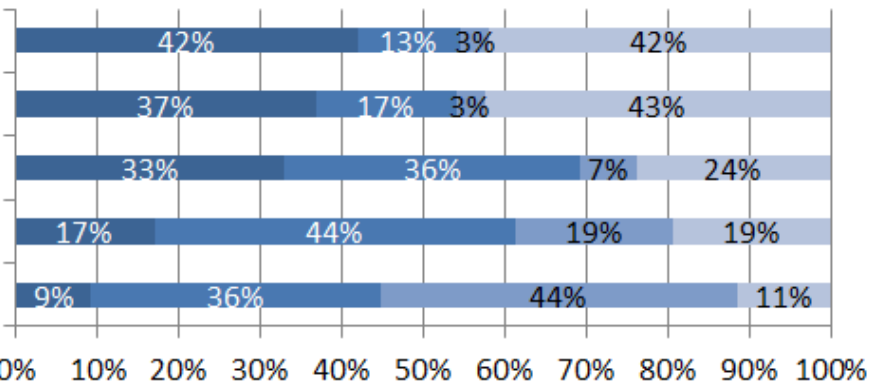

Big challenge $\quad$ Hardly a challenge $\quad$ No challenge $\quad$ No indication

Figure 8. Where do $X$ employees see main challenges when working with $Y$ (multi-selection allowed) (author's own work)

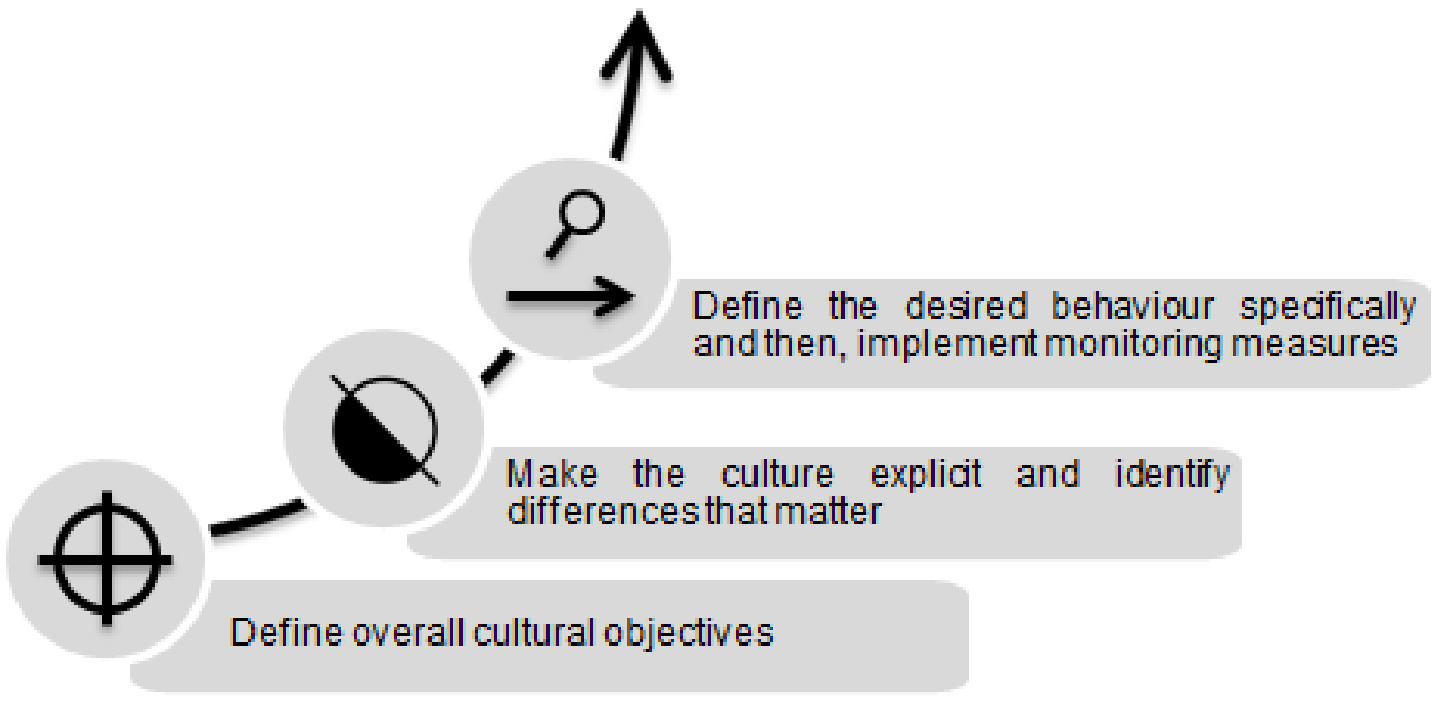

Figure 9. Systematic approach for the integration of organisational cultures (author's own work based on [29])

\begin{tabular}{|l|l|}
\hline \multicolumn{1}{|c|}{ Cultural Web components } & \multicolumn{1}{c|}{ Company $\mathbf{X}$} \\
\hline $\begin{array}{l}\text { Stories/Myths } \\
\text { (What is told about the company?) }\end{array}$ & - Start-up history \\
\hline $\begin{array}{l}\text { Symbols } \\
\text { (What are tangible or intangible symbols identifying the } \\
\text { company?) }\end{array}$ & - Founder myths \\
\hline $\begin{array}{l}\text { Rituals/Routines } \\
\text { (What internal behaviour is repeated again and again?) }\end{array}$ & $\begin{array}{l}\text { - } \text { - Emotional language in brochures } \\
\text { - Casual dress code and first name terms }\end{array}$ \\
\hline $\begin{array}{l}\text { Power structures } \\
\text { (Who has the power in the organisation?) }\end{array}$ & - Products visible across in offices \\
\hline $\begin{array}{l}\text { Control systems } \\
\text { (What is controlled and how?) }\end{array}$ & - Open door policy in chats \\
\hline $\begin{array}{l}\text { Organisational structure } \\
\text { (How the company is organised?) }\end{array}$ & - Flat hierarchies below CEO \\
\hline & - Little scrutiny/control level \\
The paradigm & - Loose working culture \\
(Basic set of assumptions and values of employees) & - Informal working processes \\
& - Personal relationships help \\
\hline
\end{tabular}

Figure 10. Example of Cultural Web components according to Gerry Johnson [2] 


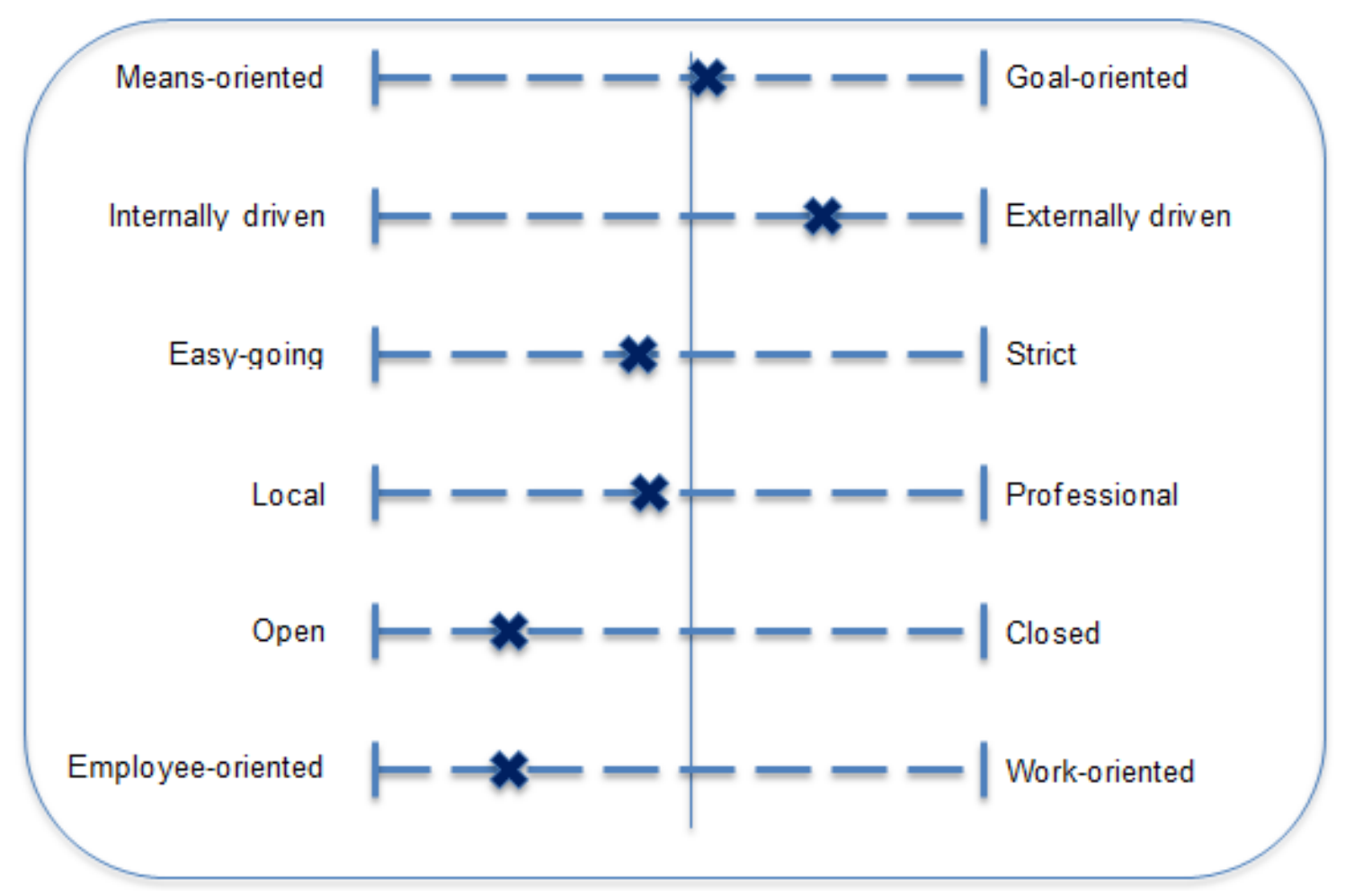

Figure 11. Average values of company $X$ on the 6 dimensions of the organisational culture according to Hofstede [30]

\section{Flexibility and Discretion}

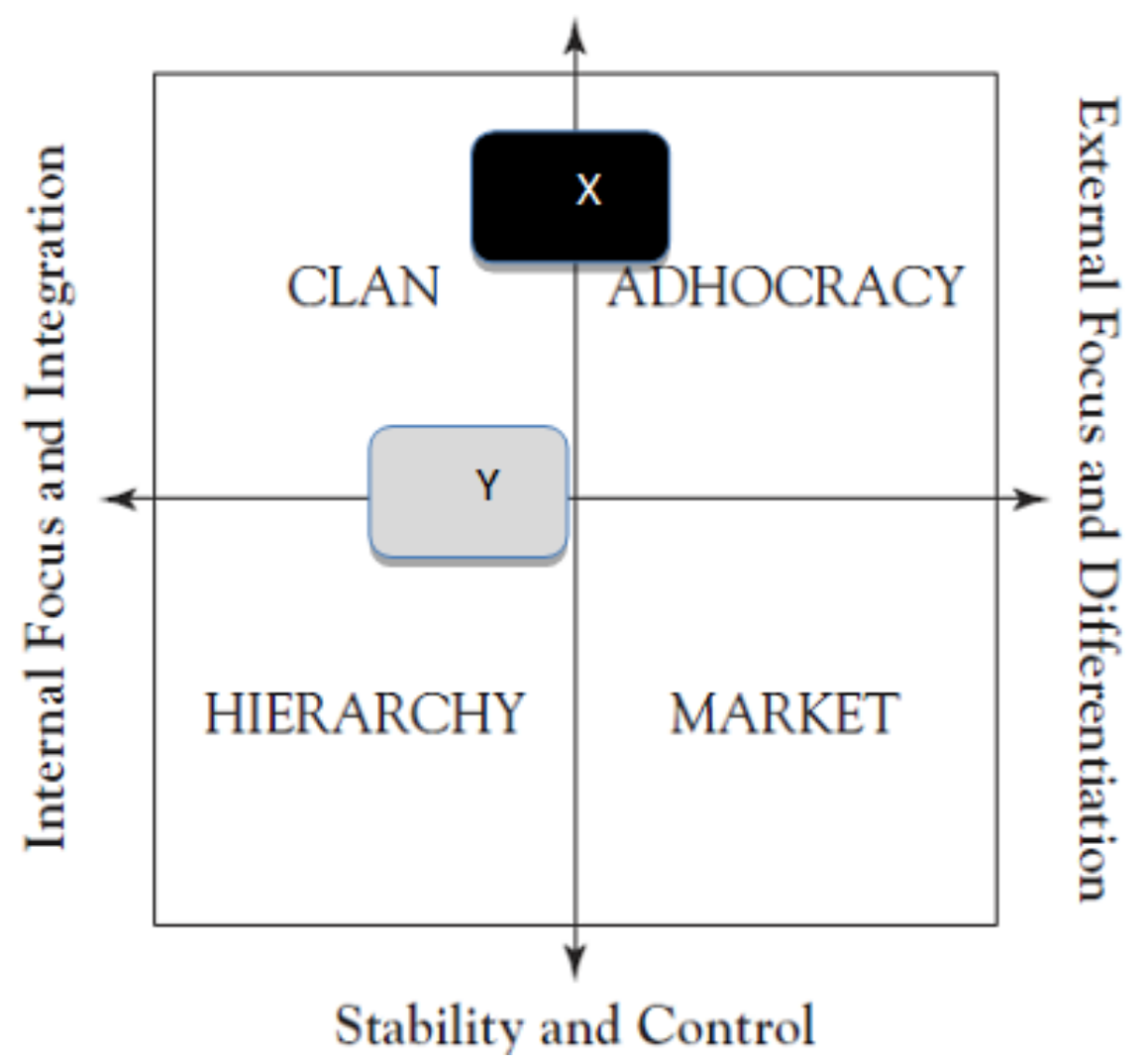

Figure 12. Competing Values Framework with regard to organisational cultures according to Cameron and Quinn [31] 


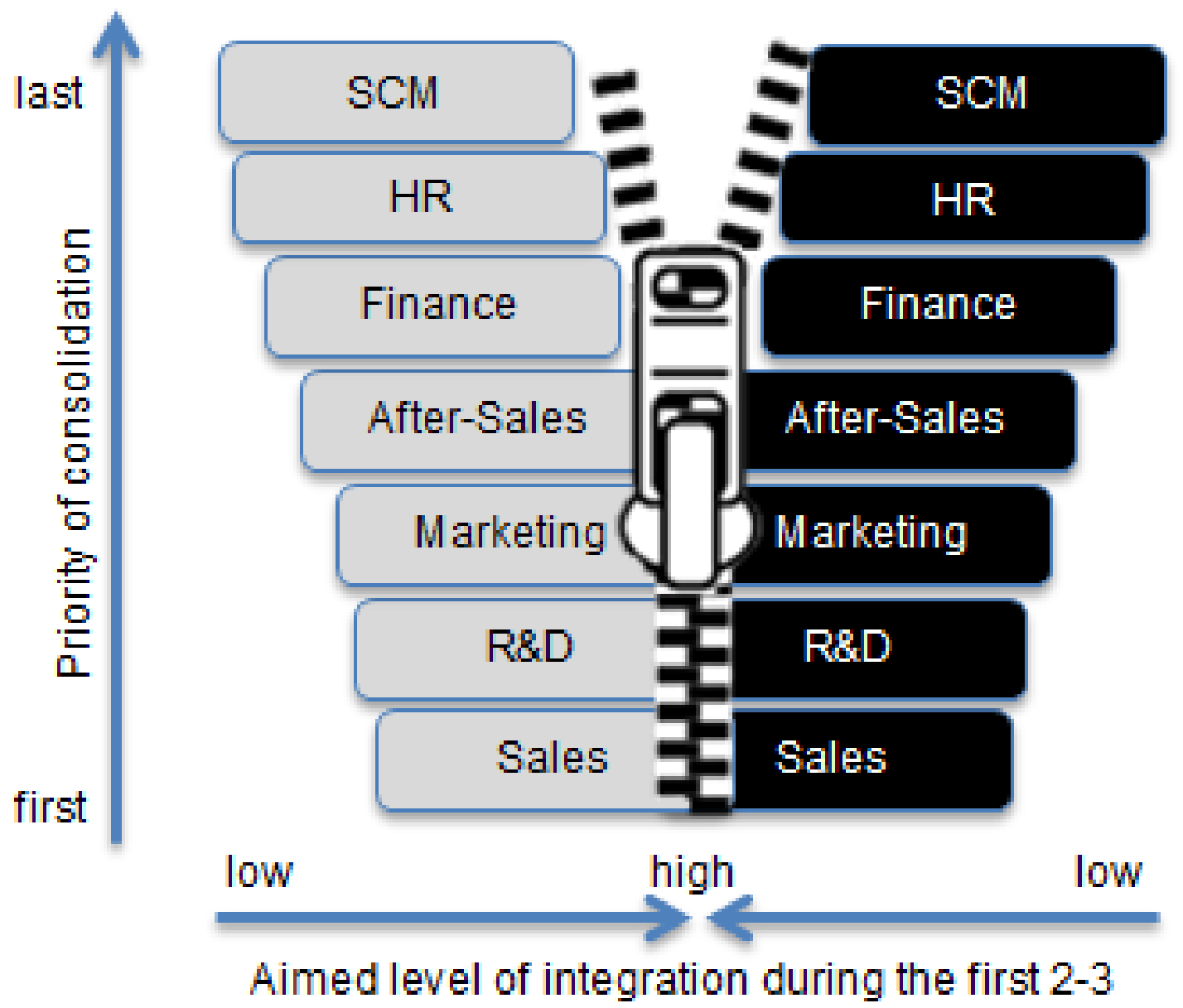

Figure 13. Zip fastener integration approach (created by author)

The dimension Performance Orientation "reflects the extent to which a community encourages and rewards innovation, high standards, excellence, and performance improvement" [23]. This category is similar to Hofstede's Masculinity dimension discussed in chapter 4.1. Examples of a high performance society are high appreciation for competitiveness and development accompanied by direct communication style. Societies with low values on this scale appreciate harmony and family relationships more than the performance and individual realisation [23].

The average total value across all nations for practices (4.1) is lower than for values (5.6) in this dimension. The authors explain this phenomenon that people think their societies actually strive more for performance than they actually do [23]. Same phenomenon can be observed for Germany and Japan. Yet, Japanese estimate their actual performance orientation soberer and thus, more to the point than Germans. The scale also shows that Japan and Germany have equal scores for practices, which both are near the balanced average and which mean that they are similarly performance oriented. This point underlines the statement made in chapter 4.1 for Masculinity dimension. As suggested by this theoretical framework, no conflicts could be observed between $\mathrm{X}$ and Y. Both the amount of mutual company activities (harmony preference) and workload (performance preference) were perceived in a similar way and accepted.

The dimension Uncertainty Avoidance was already explained in chapter 4.1. Interestingly enough the values values correspond to Hofstede's definition. However, the reality figures (practices) show that Germany is even more focused on rules and forecasts than it is the case in Japan. One explanation could be that Germans follow the rules and try to avoid uncertainty "automatically" by not thinking it is very strong societal value. Given that $\mathrm{X}$ is a much smaller company than $\mathrm{Y}$, the high emphasis on forecasting endeavoured by $\mathrm{Y}$ was rather new for $\mathrm{X}$ and $\mathrm{X}$ had to adapt its processes to it first. In this context the size of the company plays a bigger role than the culturally inherited values.

GLOBE Project offers two dimensions for collectivism. The first one is the institutional collectivism and describes "the degree to which organizational and societal institutional practices encourage and reward (and should encourage and reward) collective distribution of resources and collective action" [23]. The Germans appreciate the equality concept (value: 4.7 ), however, the practice value of 3.7 shows, that 
the institutions are not supporting this value accordingly. In Japan, the opposite is the case. The very high practice value of 5.2 for Japan, which is one of the highest in this dimension, can be demonstrated by an example from a business context. It is common practice that managers change from department to department on a regular basis to promote the collectivism feeling across the whole organisation.

The second type of collectivism is called In-Group collectivism. It is the feeling of cohesiveness and loyalty to an organisation or family [23]. Hofstede's Individualism dimension tackles similar aspects. Both models show that Japan and Germany are much closer to each other than expected, even if Japan is slightly more collectivistic, given that it is an Asian nation. Both nations lie near the average on this scale and try to create a good balance between individualistic and collectivistic approaches in life and business. Members of company X felt a strong affiliation to their employer and the place they worked in, however, within the company they identified stronger with their individual departments than with the company as a whole. In contrast, expatriates from $\mathrm{Y}$ were proud to present themselves as Y-members rather than focus on the individual division they worked for.

Power distance is also similarly defined by GLOBE project [23] as Hofstede's equally called category. It is the degree to which subordinates are willing to give power to their leaders. Yet, two aspects are worth mentioning with regard to research outcomes. First, the value values are much lower than the practice values for both nations. It means the power is significantly more controlled by the supervisors than it is wished by their subordinates [23]. Second, the practice value for Germany in this dimension is higher than in Japan, which would indicate stricter hierarchies in German organisations than in Japanese ones. In fact, many employees at $\mathrm{X}$ were unsatisfied with the information flow from the top management level. This is also a form of high power distance, as information is localised and its access is limited. Germans seem to appreciate the idea of egalitarianism across all vertical levels, but the structures and systems in place tend to provide leaders with more power than their subordinates would like to. Also slower decision-taking processes accompanied with the typical Japanese consensus seeking at $\mathrm{Y}$ indicate a flatter hierarchy and thus, lower power distance as in many other Asian countries, as there is no one manager who can make the decision on his/her own [25].

As for the Gender Egalitarianism dimension, both nations think it is an important value in society and business to promote female as well as male equality on all levels [23]. Especially, Germans are among the top ones who think this way across all survey nations. Yet, females are not that "equal" in reality as they should be according to value value. Both Germans and Japanese lie in the average range in practice value. Both companies $\mathrm{X}$ and $\mathrm{Y}$ have almost solely men on the top management level, which would support this statement.
Humane orientation differentiates between altruistic or caring society (high value) and materialistic or selfish society (low value) [23]. The average figures across all nations show that people are less interested in one another than they desire to be. It is also the case for Germany and Japan. In fact, Germans are among the lowest rated ones on the practice scale with regard to this dimension. It could not be confirmed for $\mathrm{X}$, as the company has put employee satisfaction and their well-being very high on the priority list.

Future orientation is very similar to Hofstede's long-term orientation. The values suggest also similar distribution and identify Japan as slightly more future oriented than Germany. This could be also observed between $\mathrm{X}$ and $\mathrm{Y}$, where $\mathrm{Y}$ put more emphasis on forecast and budget planning in financial department and on more long-term R\&D development planning than it was the case at the medium-sized X.

The Assertiveness dimension is "the degree to which individuals are (and should be) assertive, confrontational, and aggressive in their relationship with others" in order to get what they want [23]. The Japanese like to see themselves as highly assertive, since they depict one of the highest scores for value on this dimension. It could be attributed to the fact that they are insistent as a nation e. g. when it comes down to resisting natural catastrophes. Yet, in terms of communication Japanese are very indirect and afraid of harming the harmony by pushing their own wants into the foreground. Germans on the other side see themselves as cooperative, harmonic and as valuing warm relationships. Still, when it comes down to get what they want Germans become very focused on the task and rather neglect the relationships that could suffer. Concerning $\mathrm{X}$ and $\mathrm{Y}$ one could observe that $Y$ has not enforced many actions on $X$. In fact, the majority of employees at $\mathrm{X}$ did not feel any changes in first years accompanied by the acquisition. On the other hand, $\mathrm{X}$ had a voice in top management almost from the very beginning of the collaboration and was able to keep separate stand on a few big trade fairs as opposed to other divisions of Y.

The analysis of these nine dimensions for the two nations give the reader first insights into the values of an average member of each national society. The originality of the research results of GLOBE Project is the direct comparison of value and practice values. The outcomes show differences between how Japanese and Germans desire to see their societies and how they actually behave. Contrary to stereotypes, it is apparent that they often have very similar practices e. g. with regard to Future Orientation, Power Distance, Collectivism II (In-group Collectivism), Gender Egalitarianism and Performance Orientation (see Figure 5). In general, this promises little conflicts deriving from intercultural communication, which could be confirmed in the case between $\mathrm{X}$ and $\mathrm{Y}$. Moreover, these dimensions should be considered as a common ground when working on a cultural integration strategy in chapter 0. Additionally, 
similarities in societal value dimensions should be considered equally as these are the aspired values, which motivate the employees from both nations. The dimensions at which the scores lie close to each other between the two nations are almost the same to practice dimensions along with the Humane Orientation.

The analysis in the light of the two companies $\mathrm{X}$ and $\mathrm{Y}$ is limited, as the companies differ a lot from one another, e.g. in terms of turnover, number of employees and their company lives. These variances make the organisational cultures shift in different directions on individual dimensions from the corresponding national culture as a benchmark. One should keep in mind that companies develop their own cultures, which can be influenced by the national culture but does not necessarily overlap with them. Therefore, one should understand that the value and practice values provide an average across all companies of all sizes and industries for each nation and thus, it can be imprecise to compare two specific companies to these measurements.

The research of the 6 national cultural dimensions by Geert Hofstede and 9 dimensions by the GLOBE Project are only two out of several in this field. For further exploration of this topic the authors recommend among others, the Lewis model by Richard Lewis, distributing cultures into three main categories of Linear-active (Germany), Multi-actives (Italy) and Reactives (Japan) [26] as well as the research by Edward T. Hall on language, time and space among different cultures [27].

\subsection{German and Japanese Specific Behaviour in Business}

This section summarises the cultural contrasts based on the case study and a survey among Japanese-owned companies in the Düsseldorf area (see Figure 6). It is helpful to consider the following: if every party makes a half step towards the partner, the full understanding is almost ensured. In other words, the mere awareness and understanding of the different mind-sets can deescalate situations and improve communication with each other [1].

\subsection{Language Barrier}

The language barrier poses a major threat to communication. Many of the Japanese secondment associates and rotational managers from middle level, do not speak well English and Germans almost never speak Japanese. It is embarrassing for Japanese managers to show their lack of language competence before the team and thus, they restrict their communication to other Japanese, which often leads to a communication barrier [25].

It is important, that the Japanese actively visit language courses and Germans are encouraged to actively approach them as well as include them in common activities, such as common lunch, sport events or other celebrations, despite the perceived Japanese reservation. In presentation, the articulation should be slow and clear, while questions to the audience determine whether an aspect was understood or should be clarified. A translator or an English-speaking Japanese colleague should accompany important meetings. Preferably, the slides have been submitted to the Japanese colleagues in advance and are printed out on the day of the presentation. Possibly, one can translate essential slides into Japanese. Generally, the communication with Japanese colleagues speaking little English demands certain social skills, patience and understanding for the counterpart. One must be careful not to embarrass the other, as the loss of face is highly shameful for the Japanese [1].

\subsection{German Cosmopolitanism}

Japanese middle managers and managers on secondment have often little or no multinational experience. Hence, German managers - based on their knowledge of foreign languages and international working experience - might feel superior to Japanese managers. Conflicts may be created, when the Japanese expatriates are placed above more experienced German managers. Japanese managers might interpret German managers' boasting from own international experience as an insult or a direct threat to their hierarchical position [25].

Generally, the criticism towards a Japanese manager should be raised in private and with high respect to his/her hierarchy position. Contributions should be made in an objective manner without lowering the hierarchy status by implying a lower knowledge level of the Japanese counterpart [1].

\subsection{Japanese Politeness vs German Brusqueness}

Another strong conflict arises from the contrast between Japanese politeness and German brusqueness, or better said direct focus on problem solving. The Japanese communication is full of "the ritual gestures of deference and humility (bowing); the verb endings and forms of address that vary with the status of the parties and the formality of the occasion; the frequent insertion in normal speech of apologetic expressions (e.g. surnimasen すみません)“ [25]. In contrast, the Japanese reluctance to say 'no' in order to avoid confrontation does bother German associates, as they expect a direct communication style. The conflicts arise, when Germans mistake Japanese politeness for vagueness and insecurity, whilst Japanese perceive German direct communication as harsh and rude. This should be kept in mind, when dealing with each other [25].

\subsection{Japanese In-group}

Germans find the Japanese In-group (uchi, 内, "inside") and Out-group (soto, 外, "outside") understanding is a barrier to functioning business relationships. But in fact, the two cultures share the aversion for informality and non-authentic friendliness (see US culture), while valuing deep long-term relationships in business [25].

It must be clear that the latter takes time and effort to establish. Helpful measures are exchange of gifts, common lunches/dinners and introductory meetings for new managers. 
The German managers from company $\mathrm{X}$ in the case study perceived these meetings as unnecessary due to high personal cost and a lack of actual business decisions. However, though these steps require patience from Germans, they strengthen common relationships and hence, facilitate future work.

\subsection{Varying Acceptance of Blame}

Acceptance of blame is seen completely different by the two cultures. Japanese strongly appreciate the forthcoming assumption of own guilt as an acceptance of responsibility. For instance, higher-level managers apologise for mistakes conducted by their division and subordinates. Contrary, people from Germany exhibit an impulse to defend themselves or shift the blame to someone else. The conflicts arise when the Japanese perceive this behaviour to be arrogant and irresponsible, while the Japanese overall politeness connected with too many apologies is sometimes seen as an insecurity and lack of leadership [25]. It is recommended to avoid direct assignment of blame, as it can lead to the loss of face for the Japanese. Instead, an effective solution would be to agree how to solve an occurred problem together [22].

\subsection{Different Decision-making Approaches}

German associates expect the key decisions to be taken by individual managers, i.e. top-down. Japanese' initiative power for decisions is strongly based on mutual consensus between several employees and hierarchy levels, i.e. bottom-up approach. These varied understanding of decision-taking results in different business practices. While Germans make quicker decisions, their implementation takes normally more time, since not all of associates agree with the manager's judgement. Japanese utilise long discussions with several parties from different hierarchy levels and from different departments as a management tool to find overall agreement, before taking the final decision. However, once a decision is final, its implementation is quick and precise, since everybody is on board. These different approaches lead to misunderstanding. Germans perceive the Japanese consensus-based method (Nemawashi 根回し) as too long and sometimes as a weakness of leadership. Japanese, in turn, might see the lone top down decisions as isolating for some associates/departments [25]. The organisations must find a healthy balance between these two practices.

Furthermore, the survey revealed that the Japanese did not appear to have a particular strategic plan for their German divisions. It could also be observed that German managers have worked out solutions for their superior Japanese managers to agree on - and if not, they were asked to do so [25]. This held absolutely true for the case study at hand. Y emphasised early on that $X$ should remain autonomous and has not enforced any severe changes from the top, other than linked to legally required reporting issues. Instead, Y encouraged $\mathrm{X}$ to present its own strategy for the future that is driven by X's employees.

\subsection{Summary}

Summing up, the mind-sets vary but there are sensitive explanations behind each approach. Yet, first of all, it is important to overcome the language barrier by help of a translator and intensive language courses for non-speakers. Germans must show a lot of patience in communication and meetings. It would also be beneficial to be more careful in the formulation of criticism towards the Japanese. Finally, recognising the advantages of the apparently slower but consensus-based decision taking will help Germans to advance easier with their ideas in the Japanese environment. Understanding these differences leads to appreciation of the multicultural environment and to a more sensitive communication with each other. At the same time, the German top managers must take the role as an intermediary between their superior Japanese management and local German employees, trying to satisfy various needs of these two parties [25].

On the other hand, there are also similarities between Japanese and German ways of doing business, especially, the long-term orientation, sustainability and commitment. Additionally similarities do exist in the perception of quality and perfection in engineering [1].

\section{Survey at Company $X$}

Since associates are crucial stakeholders for the success of a merger, it is beneficial to regard their point of view more closely by means of a survey. The survey at company $\mathrm{X}$ was carried out approximately 3 years after the acquisition was officially proclaimed, and focused on the expectations, wishes and fears at company X. 90 respondents from company $\mathrm{X}$ have participated in the online survey.

The survey results show an overall positive attitude towards the merger in general. $90 \%$ have indicated "yes" when being asked the question "Do you support the merger in general?". Especially, managers indicated exclusively to be convinced by the benefits of the merger. About $70 \%$ of comments exhibited a positive opinion, while others acknowledged both chances and risks (about $25 \%$ of comments) or expressed fears of losing on the pace and flexibility of a typical medium-sized company when adapting to $\mathrm{Y}$ processes (about $5 \%$ of comments).

At the time of the survey the emotional status at $\mathrm{X}$ was rather awaiting and the personnel were eager to know how exactly the integration process and upcoming changes will look like. Generally, it appeared the employees at X were ready to start the adaptation process and have an overall optimistic opinion of the merger. However, they seem not to know what is coming, which confused some people. One question addressed the perceived changes at the time of the survey. The results showed that on average well over the half of the personnel have not perceived any changes across all inquired areas, namely workload (42\%), task variety (57\%), conflicts $(60 \%)$, level of scrutiny $(56 \%)$, structure at work $(65 \%)$, career opportunities (69\%), feeling of belonging 
(71\%), freedom of action (67\%), right to be heard (66\%) (regard Figure 7). The long hesitation phase might be attributed to careful and thus, long-term decision taking at the top management level between company $\mathrm{X}$ and $\mathrm{Y}$, being more influence by the Japanese managing style.

$\mathrm{X}$ 's personnel were convinced by the advantages of the merger with a larger corporation suggested in the question, such as integration of mutual products to one holistic customer offering $(66 \%)$ and stronger financial support (58\%).

Respondents, who have indicated the challenges, consider slow decision taking processes $(42 \%$ think it is a big challenge) and a very hierarchical organisation at Y (37\% think it is a big challenge) as the two main challenges, when working together with a large $\mathrm{Y}$ corporation. Language barrier (17\% think it is a big challenge) and separate locations ( $9 \%$ think it is a big challenge) rather seem to be small and manageable challenges (see Figure 8).

The information exchange between employees of $\mathrm{X}$ and $\mathrm{Y}$ were mostly perceived as adequate, with a slight tendency to being satisfied. A comment indicated it was the biggest challenge to find the right contact person and that sometimes people would have different information, which is a common problem with non-international mergers, too. People seemed to be better informed about the overall new strategy at $X$ in the course of the merger with Y (4.10 on a Likert scale, with 7 being very well informed and 1 being hardly informed) than about the specific upcoming changes (3.84 on the same Likert scale). These findings put the communication significance on top of the list - similar to any other merger or acquisition.

Answers from 33 persons have been submitted to the open question: "What would you suggest to the management of $X$ with regard to further cooperation with Y?". The following sections summarise and categorise the individual responses to the corresponding question. The numbers before the line indicate the amount of comments implying similar meaning.

- 19: More employee communication and transparency

- 10: Facilitate collaboration and communication between the two companies

- 9: More employee involvement in the integration process

- 8: Faster integration process

- 7: Motivation of X employees to embrace merger and increase readiness to do it

- 7: Critically consider adaption to organisation culture of $Y$ in different aspects

- 5: Strengthen the position of $\mathrm{X}$ in the $\mathrm{Y}$ group

- 3: The management does a good job

- 2: Achieve a rethinking among Y employees about the stronger role of $\mathrm{X}$ in the group

There were 43 people commenting on aspects, which should be kept at $X$ during the integration process:
- 19: relationship towards employees, partners and customers (i.e. open, loyal, personal, friendly, faithful, social, family relationship)

- 11: Short, direct, fast and non-bureaucratic communication channels

- 8: Flexibility of a medium-sized company towards the market with dynamic processes

- 7: Customer flexibility and orientation with a fast, individual and intensive service

- 6: Sports and leisure activities

- 4: Spirit as a lateral thinker of a Hidden Champion

- 3: Company culture of a medium-sized company in general

- 2: Independence and freedom of decision from the $\mathrm{Y}$ Corporation

- 2: Flat hierarchy and personal freedom of decision

- 1: Vision, strategy and company goals of $\mathrm{X}$

35 respondents have given their suggestions with regard to the question "What areas at $X$ should be improved along the integration process?":

- 7: Working in a more structured way according to defined processes

- 7: Improve internal communication and collaboration between separate departments

- 6: Continuous salary adaptation and transparency on this topic

- 5: Individual employee decisions should be made from the company perspective going beyond own personal job responsibility

- 4: Faster production development and innovation

- 4: Improve product quality and quality consciousness

- 2: Facilitate feedback culture and active employee participation in company decisions

- 1: Medium and long term development of reliable partners, suppliers and manufacturers

- 1: Stronger appearance in front of the customer

- 1: Re-consider current price strategy, as the customer discounts are steadily increasing

- 1 : Define a clear strategy and pursue it

- 1: Further education and training programmes

- 1: Provide voluntarily social services as a company

\subsection{Conclusions}

$\mathrm{X}$ associates appeared to be keen on learning more about the following integration process in the course of the merger and look generally optimistically into the future. Though the consolidation followed a very gradual approach at the time of the survey, the top-down information and the involvement of employees in the strategic decisions should be increased according to the survey. The comments indicated that several people have some specific ideas how to design the integration process efficiently and thus, want to be heard and contribute actively to the merger. Finally, there was a clear appreciation of current corporate culture of a Hidden Champion, such as family atmosphere, fast and flexible 
customer service, flat hierarchy as well as numerous sports and leisure events, which the associates care for and would like to keep. At the same time, employees would appreciate some changes which can be associated with a typical large corporation, such as structured way of working, high product quality and long-term development planning. Last but not least, the survey results could not identify any problems deriving from dealing with a different culture. This outcome is supported by several cultural similarities between Japan and Germany discussed in chapter 4 .

\section{Cultural Integration Approach on a Company Level}

In any co-operation between 2 organisations, international or national, the corporate cultures meet each other. A study has even found out that "presumed negative effect from culture distance on [international Joint Venture] performance originates more from differences in organizational culture than from differences in national culture" [28]. This is a good reason to focus on the integration of the organisational culture in the following section. Figure 9 presents an overview of the suggested steps for the systematic integration approach.

\subsection{Define Overall Cultural Objectives}

An article by Dale Stafford and Laura Miles, partners at Bain \& Company consulting, provides a number of steps as a guideline to managing the integration of corporate cultures [29]. Integrating cultures is a very "soft" topic, and there is normally no team or department who feels accountable for it. Therefore, the top management should take the main responsibility for managing the cultural integration process. The middle managers - as the role models - should be convinced to endorse the adapted culture in order to send the right signals to the rest of the organisation [29].

Firstly, it is important to define the overall objectives (e. g. market penetration, high market share, technological leadership, best customer service, etc.) of the newly emerging organisation in order to be able to agree on a cultural integration agenda. This agenda, in turn, would consist of a set of values and behavioural attitude for all organisational decisions. This will help to decide which corporate culture, either the one from Y or X should become the dominant culture as a whole or alternatively, which individual parts of the two cultures should be retained, i.e. picking best of both worlds [29].

According to Schuhbauer and Wellner management of $\mathrm{X}$ and $\mathrm{Y}$ should agree together to answer the following questions [6]:

- What are our core values with regard to our customers (e.g. quality products, fast after-sales service, competitive prices, extensive consulting, etc.)?
- What are our preferred internal organisation and management structures (i.e. flat hierarchies and high personal responsibility vs. autocratic leadership with high hierarchy and bureaucracy)?

- What kind of employee behaviour is particularly rewarded (e.g. long company affiliation, strong performance, social achievements, team skills, etc.)?

- Do we frequently react to markets in the short term or should we rather develop our own products for the long run?

- $\quad$ Do we pursue stability (i.e. stick to proven concepts and products) or innovation (i.e. try to develop frequently new products and systems)?

- Does decision making happen in a centralised (i.e. from $\mathrm{Y}$ headquarters, top-down) or decentralised (i.e. at every business-unit, bottom-up) manner?

- What kind of importance do trust and reporting to the HQ play?

\subsection{Make the Culture Explicit and Identify Differences that Matter}

Gerry Johnson [2] suggests that the cultural forces normally drive the personnel at an unconscious level. In order to facilitate changing the culture, which is taken for granted, is to make it explicit through an analysis. There exist several models, which help to understand and visualise the corporate culture. Figure 10 and Figure 11 present examples of these tools applied for the German company X.

As a third model presented here, Figure 12 shows the Competing Values Framework from Quinn and Cameron defining 4 main organisational cultures. The hierarchy culture presumes a hierarchical organisation structure, bureaucratic processes and standardised control mechanisms (i.e. doing things right). The clan culture is known as a family-type organisation with cohesion, mentoring management style and corporate commitment to employees (i.e. doing things together). The market culture is result-oriented and involves a demanding workplace. It puts emphasis on beating the competition and gaining market share and penetration (i.e. doing things fast). Finally, adhocracy culture helps to respond quickly and flexibly with innovative and risk-taking actions to the dynamically changing environment (i.e. doing things first). These 4 cultures represent extremes and any organisation is normally a mixture of them with a particular focus on one or two of them [31].

After having made the cultures explicit, the differences between them need to be analysed. Those which do matter AND clash must be tackled, i.e. it must be decided which of the two cultures should dominate the other at this very difference [29].

While Y exhibits a mix between hierarchy and clan culture in view of the Japanese influence from the parent company and its hierarchical structure, $\mathrm{X}$ used to pursue the adhocracy method by adapting the product range to the market 
conditions and wishes (see Figure 12). The management has to agree which attitude should prevail in common operations as otherwise conflicts will slow down integration and overall performance. Simultaneously, the management should consider the overlapping of both organisations with regard to the clan culture when dealing with employees and use this similarity as the basis to start the cultural integration [6].

In the case at hand, it would entail promoting common employee activities. With regard to customers, one should hold on to the flexibility as well as fast reaction culture at X, while implementing Y's stronger control and long-term focus in internal processes to a certain degree, such as $R \& D$ and Finance, to ensure stability. As $\mathrm{X}$ is stronger present and more aware of the market in Europe, the Middle East and Africa (EMEA) compared to Y, much of the working culture, i.e. "the way how things are done", should be based on X's understanding. In Asia, in turn, Y's managers should take the lead to decide for dominant parts of the culture.

Besides, it is not necessary to sync the culture across all departments. Figure 13 exhibits an overview of the suggested required level of integration across various departments at $\mathrm{X}$ and $\mathrm{Y}$. The vertical priority axis symbolises in which department the consolidation is more important. The initial level of integration - indicated by the horizontal axis - is expected to increase over time, which is shown by the closing zip fastener.

For example, the procurement cultures do differ, as $\mathrm{X}$ seeks out the best price/quality ratio, while $\mathrm{Y}$ focuses on long-term relations with affiliated business units. However, this difference does not matter, as the nature of procured materials varies and individual procurement operations do not directly affect common activities [32]. In contrast, R\&D departments started to work together and $X$ had to adapt to the long-term planning processes at $\mathrm{Y}$ to ensure a consistent approach. The two mostly independently operating sales teams should also approach each other and coordinate their sales operations. It appears, while sales representatives from $\mathrm{X}$ convince with the price, $\mathrm{Y}$ emphasises the quality of its products. These approaches should be coordinated to create a consistent image and to fully exploit synergy sales [32].

\subsection{Define the Desired Behaviour Specifically and Then, Implement Monitoring Measures}

Thirdly, the desired image of the future common culture becomes more and more apparent to the management. This vision will serve as a guideline for the definition of upcoming measures and ways to cooperate at the new organisation. Therefore, it must be broken down to the level of individual behaviour at all levels and departments. The employees must not only understand the inhibited values and attitudes, but also start executing them in their daily work every time more and more [29].

The communication should convey the big picture and then, the specific expected behaviour for every associate. In other words, employees need first to understand what the new values of the changed organisation are, before they can carry out their tasks in line with them. Aligning the personnel to work together in the similar manner is a great challenge of cultural integration and management, in general.

Finally, the company must encourage this particular behaviour through monitoring and incentive measures [29]. These tools are helpful measures for managers to guide the actions in the desired direction.

In the survey, the new corporate culture of the merged organisation should become fast but also reliable at the same time. As for the sales teams, the specific behavioural guideline could be to offer fast customer service. First, trainings must equip employees with necessary knowledge and then, the performance of sales representatives can be monitored based on the reaction time to customer requests. Another example for precise behaviour would be the compliance with standardised processes by internal employees, which should be assessed with corresponding monitoring systems, after the personnel have been instructed appropriately [32].

\subsection{Summary}

Cultural clash and different attitudes of working are probably with arrogance/non acceptance of the diverse partner, the major reasons for failure among mergers irrespective of national or international ones [29]. Thus, the cultural aspect must not be neglected. This section has presented a step-by-step approach for management how the cultural integration between two organisations can be pursued. It suggests that the cultural framework derives from the objectives of the newly formed company as well as considers the status-quo corporate cultures by making them explicit and focusing on their relevant differences.

The approach also indicates the importance of making the cultural/ work attitude framework, which was developed and agreed on by the top management, tangible for the subordinate employees by making explicitly clear which behaviour in certain situations is expected from them. It is recommended to respect and potentially leave irrelevant differences untouched, while focusing more on the critical differences. As the case study has shown, it is possible that the acquirer adapts partly to the acquiree and vice versa, in order to keep the best of both worlds. Finally, the necessary monitoring and incentive systems must be put in place to achieve perpetual change towards the desired organisational culture in the long run. At the end of the day, successfully integrated culture, in which employees behave consistently and understand the inherent values, can boost the overall integration process substantially.

\section{Conclusions}

Successful cultural integration is one of the key success factors in any M\&A and it is particularly true in co-operations across national borders, where associates have 
values and behaviour originating not only from their organisational but also their national culture. This paper presented a case study and suggested a number of sticking points to be resolved in order to find the same "language" in the cooperation.

In the integration process, the top management is normally chiefly occupied with political, strategic and tactical decisions. In this course, cultural integration is often neglected. This is a crucial mistake. First, the process can only be effectively led from the top management level thanks to its eagle eye view. Second, there is high risk that this topic will be missed out entirely, as there is usually no other department feeling accountable for this task or ready to take it on in the middle of the busy reconstruction process. Thus, it is important to dedicate a corresponding top managerial priority to this topic in the post-merger integration process.

It is beneficial for managers to get acquainted with possible pitfalls with regard to the differences in national cultures (compare section 0 ). The mutual understanding will make the cooperation more comfortable and accelerate the integration process.

The final chapter shows a possible systematic methodology for a rather soft topic. Following it will help the managers to achieve change more effectively and in a more sustainable way.

Cultural integration is a long-term process and takes several years, as the employee mind-sets cannot change overnight. Therefore, one must leave each other enough time to adapt. Yet, the top management should also have an actual roadmap with specific measures in order to achieve change, even if it is a gradual change.

\section{REFERENCES}

[1] Schremf A, Wellner KU. Asiatischer Tigerstaat und buddhistische Tradition. OHM Journal. 2013;: p. 68-69.

[2] Johnson G. Managing Strategic Change - Strategy, Culture and Action. Long Range Planning. 1992; 1(25): p. 28-36.

[3] Bradt G. Forbes. [Online].; 2015 [cited 2016 March 28. Available from: HYPERLINK

"http://www.forbes.com/sites/georgebradt/2015/06/29/the-ro ot-cause-of-every-mergers-success-or-failure-culture/"\1 "2f105a652173"

http://www.forbes.com/sites/georgebradt/2015/06/29/the-roo t-cause-of-every-mergers-success-or-failure-culture/\#2f105a 652173 .

[4] Wellner KU. Analyse integrativer Managementsysteme zur Führung internationaler Familienunternehmen in Management und Controlling. 2010 October 12.

[5] McGrath C. Thought Farmer - Social Intranet. [Online].; 2014 [cited 2016 March 28. Available from: HYPERLINK "https://www.thoughtfarmer.com/blog/culture-clash-mergers -software/"

https://www.thoughtfarmer.com/blog/culture-clash-mergerssoftware/.
[6] Schuhbauer W, Wellner KU. Umfeldbeobachtungsnetzwerk als strategisches Tool zur innovativen

Unternehmenssicherung. Controller Magazin. 2007 June;: p. 636-643.

[7] Wellner KU. Hidden Champions in der Provinz. Jahrbuch Consulting 2013 - Jahrbuch der Unternehmensberatung 2013. 2013 October;: p. 48-57.

[8] GE Capital. Triebwerk des erfolgs - der deutsche Mittelstand im Fokus. s.1.: GE Capital; 2015.

[9] Simon H. Die heimlichen Gewinner (Hidden Champions): Die Erfolgsstrategien unbekannter Weltmarktführer. 5th ed. Frankfurt/Main: Campus Verlag; 1996.

[10] Rammer C, Spielkamp A. Hidden Champions - Driven by Innovation - Empirische Befunde auf Basis des Mannheimer Innovationspanels. Mannheim: Zentrum für Europäische Wirtschaftsforschung; 2015.

[11] Wellner KU. Hidden but Champions in the Province Controlling Internationalisation Strategy of hidden success midsize companies in Coburg, Northern Bavaria, Germany. In CARF Konferenz; 2016; Lucerne.

[12] Simon H. Hidden Champions of the 21st Century. In DEG The Atrium Dialogues 2010; 2010; Cologne.

[13] Simon H. Hidden Champions - Aufbruch nach Globalia: Die Erfolgsstrategien unbekannter Weltmarktführer Frankfurt a.M.; 2012 .

[14] Wellner KU. CARF Luzern 2016 Controlling. Accounting. Risiko. Finanzen. In Nadig L, Egle U, editors. ; 2016; Lucerne: Verlag IFZ - Hochschule Luzern - Wirtschaft. p. 169-190.

[15] Simon H, Lippert S. Hidden Champions des 21. Jahrhunderts - Mittelständische Marktführer in Deutschland und Japan im Vergleich - Teil I: Was macht ein Unternehmen zum "Hidden Champion"? Japan Markt. 2007 April: p. 8-15.

[16] Lippert S, Simon H. Hidden Champions des 21. Jahrhunderts - Mittelständische Marktführer in Deutschland und Japan im Vergleich - Teil II: Erfolgsstrategien und Herausforderungen deutscher Hidden Champions in Japan. Japan Markt. 2007 October: p. 22-27.

[17] Germany Trade \& Invest. Ausländische Direktinvestitionen in Deutschland - Potenziale Japan. [Online].; 2014 [cited 2016 May 12. Available from: HYPERLINK "https://www.gtai.de/GTAI/Content/DE/Invest/ SharedDocs /Downloads/GTAI/FDI/japan.pdf?v=3" https://www.gtai.de/GTAI/Content/DE/Invest/ SharedDocs/ Downloads/GTAI/FDI/japan.pdf?v=3.

[18] FAZ. Japanische Firma kauft Automobilzulieferer Hay. [Online].; 2016 [cited 2016 May 10. Available from: HYPERLINK

"http://www.faz.net/agenturmeldungen/unternehmensnachric hten/japanische-firma-kauft-automobilzulieferer-hay-142232 84.html"

http://www.faz.net/agenturmeldungen/unternehmensnachric hten/japanische-firma-kauft-automobilzulieferer-hay-142232 84.html.

[19] Hofstede G, Hofstede GJ, Minkov M. Cultures and Organizations: Software of the Mind. 3rd ed. New York: McGraw Hill Professional; 2010. 
[20] Hofstede G. the hofstede centre - Strategy, Culture, Change. [Online].; n. d. a [cited 2015 November 30. Available from: HYPERLINK "http://geert-hofstede.com/japan.html" http://geert-hofstede.com/japan.html.

[21] Haak R. Arbeitswelten in Japan Haak R, editor. München: iudicium Verlag; 2006.

[22] SinaLingua. Erfolg in Japan - Interkulturelles Training. Heidelberg: Cross-Cultural Management; 2014.

[23] House RJ, Hanges PJ, Javidan M, Dorfman PW, Gupta V. Culture, Leadership, and Organizations: The GLOBE Study of 62 Societies. 1st ed.: SAGE Publications; 2004.

[24] The GLOBE Project. GLOBE - Global Leadership \& Organizational Behavior Effectiveness. [Online].; 2004 [cited 2017 January 11. Available from: HYPERLINK "http://globe.bus.sfu.ca/study 2004 2007" VI "data" http://globe.bus.sfu.ca/study_2004_2007\#data.

[25] Lincoln J, Kerbo H, Wittenhagen E. Japanese Companies in Germany: A Case Study in Cross-Cultural Management Industrial Relations: A Journal of Economy and Society. 1995 July; 34(3): p. 417-440.

[26] Lewis R. When Cultures Collide, Third Edition: Leading Across Cultures. 3rd ed. International NB, editor. Boston: Nicholas Brealey Publishing; 2006.

[27] Hall E. Changing Minds. [Online].; 2006 [cited 2015 November 30. Available from: HYPERLINK "http://changingminds.org/explanations/culture/hall_culture. htm"http://changingminds.org/explanations/culture/hall_cult ure.htm.
[28] Pothukuchi V, Damanpour F, Choi J, Chen CC, Park SH. National and Organizational Culture Differences and International Joint Venture Performance. Journal of International Business Studies. 2002: p. 243-265.

[29] Stafford D, Miles L. Bain \& Company. [Online].; 2013 [cited 2016 February 1. Available from: HYPERLINK "http://www.bain.com/publications/articles/integrating-cultu res-after-a-merger.aspx" http://www.bain.com/publications/a rticles/integrating-cultures-after-a-merger.aspx .

[30] Hofstede G. the hofstede centre - Strategy, Culture, Change. [Online]; n. d. b [cited 2015 November 24. Available from: HYPERLINK "http://geert-hofstede.com/organisational-cult ure.html" http://geert-hofstede.com/organisational-culture.ht $\mathrm{ml}$.

[31] Cameron KS, Quinn RE. Diagnosing and Changing Organizational Culture - Based on the Competing Values Framework. 2nd ed. San Francisco: John Wiley \& Sons; 2006.

[32] Russo B, Wellner KU. Möglichkeiten der Preisharmonisierung und Controlling-möglichkeiten der internationalen Ersatzteilpreissystematik. Controller Magazin. 2009 May;: p. 36-42.

[33] Venohr B. Das Erfolgsmodell der deutschen Weltmarktführer. In Langenscheidt $\mathrm{F}$, Venohr $\mathrm{B}$, editors. Lexicon der deutschen Weltmarktführer.: Deutsche Standards; 2014.

[34] von Hassell J, Rickes S. So gewinnt der Mittelstand! - Die Erfolgsmethode kleiner und mittlerer Unternehmen (und was die großen von ihr lernen können) Wiesbaden: Gabler Verlag; 2008 . 